\title{
CULTURAL INTERFERENCE ON THE USE OF ENGLISH SECOND-PERSON PRONOUN BY JAVANESE STUDENTS
}

\author{
Retno Setya Budiasningrum
}

English Lecturer, Politeknik LP3I Jakarta, Indonesia

Corresponding Author Email: retnosb18@gmail.com

\begin{abstract}
A B S T R A C T S
Learning a language is not only about grammar and vocabulary but also about culture. Understanding culture allows language learners to give the right meaning to each word learned. English has a different culture from Indonesian. This study described the students' problems in using the second - person pronoun "you" in English, by looking at the term of social and cultural variables that are given in written form test. It involved the 40 students in ninth grade of SMP Sriwedari Malang, 80 students of SMA 3 Surabaya and 80 students of SMA 17 Surabaya. To examine the appropriateness of using second - person pronoun "you" the following steps were taken; analyzing the pronominals used by the samples, tabulating the pronominals used and the addressee interactions and the last step was calculating the percentage of pronominals used. The obtaining answer from the test explained that students' answers were various. There were "you" as kinship term and others form were found to take the place of "you". Kinship terms are "grandfather", "aunt", "uncle", "mother", "brother" and "father". Other forms include "he", "Herlina" (name), "Herman and "Levina" (names). It was found that 25.3\% students used the correct form "you", 69.05\% students used kinship terms and $5.65 \%$ students used other forms. The analysis showed that there are some errors made by Javanese students in using the second person pronoun "you" in English. It indicated that they still have culture interference in using second - person pronoun "you" in English.
\end{abstract}

\author{
A R T I C L E I N F O \\ Article History: \\ Received: October, 2020
}

Revised: November, 2020

Published: December, 2020

Keywords:

Culture Interference,

English Second-Person

Pronoun,

How to cite: Budiasningrum, R. (2020). Cultural Interference on the Use of English Second-Person Pronoun by Javanese Students. Jo-ELT (Journal of English Language Teaching) Fakultas Pendidikan Bahasa \& Seni Prodi Pendidikan Bahasa Inggris IKIP, 7(2), 125-134. doi:https://doi.org/10.33394/jo-elt.v7i2.3242

\section{INTRODUCTION}

Language is a part of culture. Language is more than the sum of grammar and vocabulary because language is always situated and contextualized by culture Fichtner and Chapman (2011:121). "It has been emphasized that without the study of culture, teaching L2 is inaccurate and incomplete", Genc, B. \& Bada (2005:73).

"...language study is both knowledge and performance, awareness and experience. It is the recognition of this boundary between the familiar and the unfamiliar and the actual crossing of that boundary." -Claire Kramsch in Fichtner and Chapman (2011:116). In studying a foreign language, it is important for learners know the culture of the language they learned. "The study of a foreign language allows learners to know another culture, not only by the expansion of language experiences, but also by including social and human factors", Mazari and Derraz. (2016:351). In the learning process, the persons who learn the language need to be aware of not only the nature of the language but also its culture. Moreover, Genc, B. \& Bada (2005:75) stated, "Culture classes have a humanizing and a 
motivating effect on the language learner and the learning process. They help learners observe similarities and differences among various cultural groups."

Consider the culture of English is different from Indonesian culture, it is required for the learners not to ignore the cultural dimensions. Relating to the culture, the study of English pronominal is a kind of different thing for Indonesian learners. It is because the system of English pronominal is different from the system of Indonesian pronominal. "Table 1 and Table 2 show the differences between the two" Morin (2005:181-194).

Table 1

English Pronominal

Singular

\begin{tabular}{|c|c|c|c|c|}
\hline & & Singular & & plural \\
\hline $1^{\text {st }}$ person & & $I$ & & we \\
\hline 2nd person & & & & \\
\hline 3rd person & masculine & Feminine & neuter & \\
\hline & he & She & it & they \\
\hline
\end{tabular}

Table 2

Indonesian Pronominal

Singular

Plural

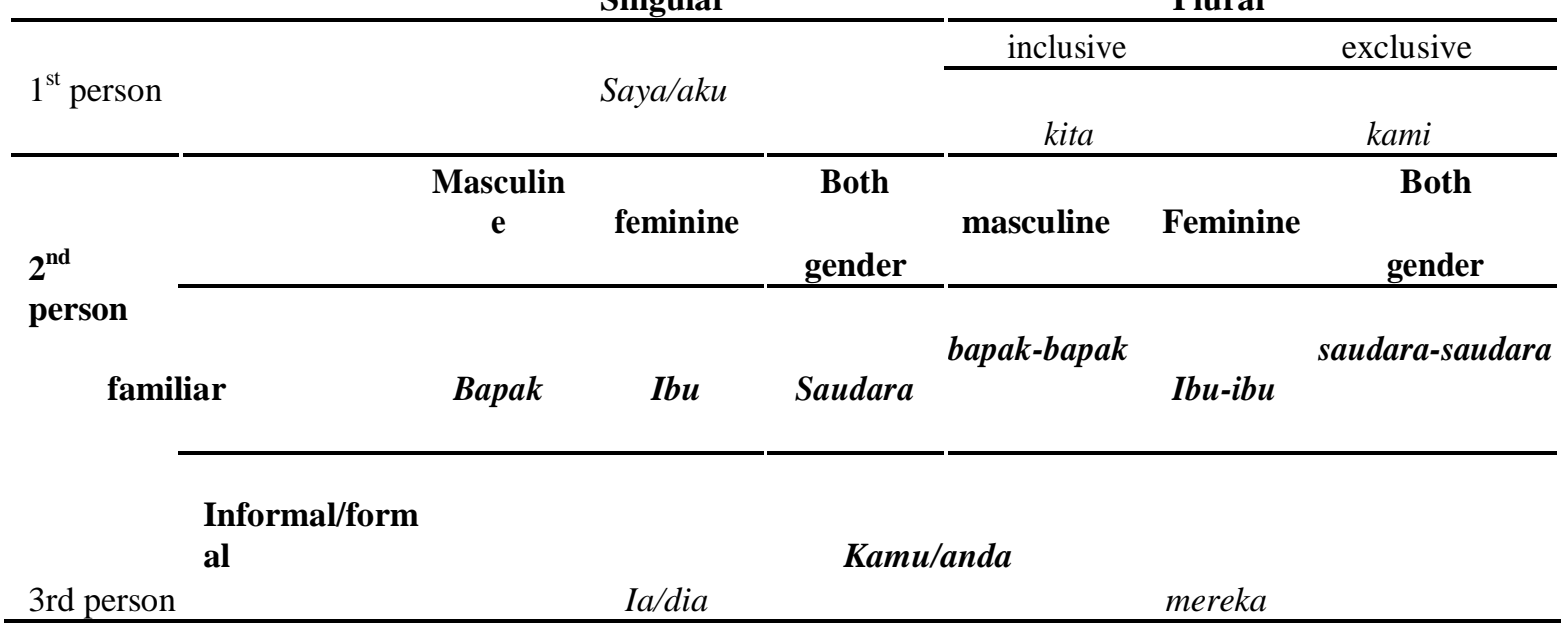

It can be seen that the form of English second - pronoun in table 1 is only 'you'. In table 2, it is showed that the form of Indonesian second-pronoun has many forms, which are 'bapak' for masculine (singular) and 'ibu' for feminine (singular), 'bapak-bapak' masculine (plural), ibu-ibu (plural), 'saudara-saudara' for both genders, 'kamu'(informal) and 'anda' (formal). As Yusuf, Nasir, and Andib (2019:77-78) stated "English has only one form of second pronoun 'you' while Indonesian has many forms, including the use of kinship terms such as bapak (father or sir), ibu (mother or ma'am), paman (uncle), bibi (aunt), kakak (elder sister/brother), adik (younger sister/brother), etc., as a substitute of kamu 'you'". In an English-Indonesian dictionary, 'you' [y'u] is listed as kamu, engkau, anda, saudara, and kau in Indonesian yet these are not given detailed explanations which may cause learners confusion about the correct form of address". "English does not distinguish between a formal and an informal address pronoun because the use of 'you' is associated with neutrality and a strategy to avoid speakers in expressing 'any overt stance of respect or familiarity towards their interlocutor", Formentelli (2009:182). "This is to say that interactions between English speakers do not display pronominal codes of social deixis", Yusuf, Nasir, and Andib (2019:81).

"The Javanese language is widely known for its speech levels: ngoko 'low' and krama 'high' which enable its speakers to show intimacy, deference, and hierarchy among its speakers",Wajdi et al. (2010:2). They use "krama" to address the people in high level of 
society. It is kind of impolite in using "low" speech level to address elderly people or the people in high rank for Javanese people. As Krisnanda (2015 :2) claimed "In Javanese, language use, especially in addressing someone, greatly affects the social behavior of society. Javanese uses the address form based on the level of their society, kinship, and closeness relationships between speaker and hearer". According to Kusumastuti (2018:388) "The different ways of using address forms can be seen from various aspects, such as the use of names, titles, kinship terms, and personal pronouns. Furthermore, Krisnanda (2014:2) stated "Age, sex, kinship term, and social status determine the ways of speaking politely".

Clifford Geertz (1960) in Quinn (2011), puts it in his Religion of Java: “... in Javanese it is nearly impossible to say anything without indicating the social relationship between the speaker and the listener in terms of status and familiarity." It is common for Javanese people to address by 'mas' and 'bapak' for male and 'mbak' and 'ibu' for female not only to family members but also to others people. In addressing 'you' they use the form of mba, mas, bapak, ibu, pakde, bude, eyang instead of 'you'. It is a kind of impolite expression if they use the word 'you' to form the second-pronoun. They keep maintaining the principle of respecting others. As Suseno (in Prayitno 2011:36) in Kentary, Ngalim, and Prayitno (2016:62) declared "There are two basic principles of speaking that are important for Javanese to know, namely the principle of respecting others and maintaining harmonious relationships". And Nuryantiningsih and Pandanwangi (2018:383) also said "in Javanese society, a person is categorized as polite speaker when the person can use level of Javanese speech correctly". Fitriah and Hidayat (2018:27-34) expressed that "A cultural convention of politeness refers to judgment of people ${ }^{\text {ee }}$ speech behaviour on the basis of the community $\mathrm{s}$ social values." Therefore, there are a lot of norms that Javanese people should obey. As Kentary, Ngalim, and Prayitno (2016:61-71) claimed that "Culture, especially Javanese culture, regulates human behavior by there are certain norms that must be obeyed."

Accordingly, Javanese learners who study English transfer their culture to English unconsciously. As they addressing the word 'you' the forms that emerge are forms that they use in their native language such as mas, mba, bapak, ibu, bude, pakde. The culture automatically influences the learning process. Interference of the culture of Javanese toward English has been found in studies of Javanese speaker in using English word "You". It appears almost in every conversation that have the word "you". These cultural differences, make students difficult in using the word "You" automatically in proper way.

\section{RESEARCH METHOD}

\section{Research Design}

This research is a descriptive study that describes the students' problem in using the second-person pronoun "you" in English, by looking at the term of social and cultural variables that are given in the written test. The choice of this design is based on the consideration that this study only examines how Javanese students use the second-person pronoun "you" in English.

\section{Population and Sample}

The population was taken from the ninth grade students of SMP Sriwedari Malang, the tenth-grade students of SMA 3 Surabaya, and the eleventh grade of SMA 17 Surabaya. The samples were taken from a population that was 40 students in ninth grade at SMP Sriwedari Malang, 80 students in tenth grade at SMA 3 Surabaya, and 80 students in eleventh grade at SMAN 17 Surabaya. 


\section{Instruments}

In collecting data, the students were asked to express the use of "you" in the written test given in English. Those sentences are as follows:

1. Kakek mau pergi kemana? (kepada kakek anda)

2. Ibu, apa yang sedang ibu cari ? (kepada ibu anda)

3. Bisakah bapak mengantar saya ke sekolah? ( kepada bapak anda)

4. Bisakah bapak menjemput adik sore ini? (kepada sopir anda)

5. Tante mau minum apa ? (kepada tante anda)

6. Apa yang kakak lakukan setiap hari Minggu? (kepada kakak laki-laki anda)

7. Kapan bibi pulang ke desa ( kepada pembantu anda)

8. Tolong bapak bawakan bunga-bunga ini ke rumah saya. (kepada tukang becak)

9. Dimana ibu membeli buku-buku itu? (kepada guru anda)

10. Apakah paman pergi juga malam mini ? (kepada paman anda)

It doesn't mean that the students have to translate those questions into English. Since the influence of Javanese culture in using the second-person pronoun "you", the researcher needs to find out whether they use the second-person pronoun "you" inappropriate way when they are asked to write those questions in English. The second-person pronoun that is used by the addressee is distinguished into those that are used to address parents (father and mother), sibling (brother), intimate elders (aunt, uncle, and grandfather), and non-intimate elders (driver, and becak driver). And the data were examined in terms of the participants' age, relationship, and intimacy.

\section{Data Analysis}

In data analysis to examine the appropriateness in using the second-person pronoun "you", the following steps are taken: (1) Transcribing the data; (2) Tabulating the pronominals used in term of the speaker and the addressee in the interaction; (3) Calculating the frequency of the use of each pronominal used based on the item 2. In analyzing the problems the observer uses descriptive method. Whatever exists in the datas will be described as clearly as possible by ignoring the structure.

\section{RESEARCH FINDINGS AND DISCUSSION Research Finding}

From the answers that have been given by the students of SMP Sriwedari Malang, SMAN 3 and 17 Surabaya, it turned out that the students' answers were various. There were several ways that students used to address the elderly male such as:

To the grandfather of the students

Kakek mau pergi ke mana ? (kepada kakek anda)

Grandfather want go are where?

Where grandfather will go ?

Where will go grandfather?

Where grandfather going to ?

Where will you go grandfather?

The pronoun "kakek" in "kakek mau pergi kemana?", there were many students who change the word kakek into grandfather, instead of "you".

To the father of the students

Bisakah Bapak mengantar saya ke sekolah ? (kepada ayah anda)

Will can father escort me to school?

Can the escort I go to school, Dad?

Can father escort me to school? 
Father can escort me go to school?

Can you escort me to school?

The pronoun "bapak" in the sentence "Bisakah bapak mengantar saya ke sekolah"? (to the father). The students gave various answers such as ; father, dad and you. Lexically "father" and "dad" mean bapak but if it refered to the context "father" and "dad" should be changed into "you ".

To the driver of the students and pedicab driver

Bisakah bapak menjemput adik sore ini ? (kepada sopir anda)

Father can pick up young brother this morning?

Can father pick up sister this evening, sir?

Sir, can you pick up my young brother this evening ?

Can pick up brother this evening, Sir ?

Can you pick the brother up this evening?

Tolong bapak bawakan bunga-bunga ini ke rumah pak Amin? (kepada bapak becak)

Please father, brings flowers to home to Amin?

Sir, help to bring this flowers to pak Amin house?

Help father bring flowers this the house pak Amin ?

Father help me bring flowers is house Mr. Amin ?

Please, you are bring this flower to pak Amin house ?

The pronoun "bapak" in "Bisakah bapak menjemput adik sore ini?" (to the driver) and in "Tolong bapak bawakan bunga-bunga ini ke rumah pak Amin?" (to "becak" driver) were answered by the students as : $\underline{\text { father}}, \underline{\text { sir, }}$ and you. Actually "father" and "sir" have the same meaning with "bapak", but if it based on the statement above they should change that word into "you".

To the brother of the students

Apakah yang kakak lakukan setiap hari Minggu ? (kepada kakak laki-laki anda)

What is he doing every week ?

What are brother doing every Sunday?

What Lexono doing every Sunday?

What are you doing every Sunday, young brother?

What are you doing every week?

Students gave various answers, such as: brother, Lexina, he and you for the pronoun "kakak" in "Apa yang kakak lakukan setiap hari Minggu?" (to the brother). Lexically brother and old brother mean 'kakak" (brother). Hence, they made mistake. They should use "you" because they talked to the second person. As well as the use of Lexono, since the observer did not want the students to use the name of someone but the second - person pronoun "you", it became a mistake. Using he, in this case, is also wrong because "he" refers to the third person and the observer wanted the students talked to the second person directly. Therefore, the expected pronoun was "you".

To the uncle of the students

Apakah paman pergi juga mala mini ? (kepadapaman anda")

Will uncle go, too. This night?

What is uncle going too these night?

What are you going to night, uncle?

What you go too this night uncle?

What uncle go too night? 
There are various answers that have been given by the students for the pronoun "Paman" in " Apakah pamana pergi juga malam ini ?" (to the uncle), such as; uncle, you and Anthonius. Lexically "uncle" means paman. Since it referred to second person directly "uncle" should be changed into "you". As well as the use of "Anthonius", it was wrong because the observer did not ask students to change the word "paman" into the name of someone.

The several ways that students used to address the elderly female are as follows:

To the mother of the students

Ibu, apa yang sedang ibu cari ? (kepada ibu anda)

What looking for, mother?

Mother, what are mother look for?

Mother, what look for mother?

Mother, what are you looking for?

What mother looking for?

Many students used "mother| instead of "you" for the pronoun "ibu" in "Apa yang sedang ibu cari ?". Lexically mother means "ibu", whereas, if it is based on the context they should use "you" in English.

To the aunt of the students

Tante mau minum apa? (kepada tante anda)

What will drink aunt?

What would aunt like to drink?

What would Herlina like to drink?

What would you like to drink?

What aunt like to drink

The various answers for the pronoun "tante" in " Tante mau minum apa?" that students gave such as; you, aunt, and Herlina. Actually, "aunt" means tante. But if it turned back to the statement above the word "aunt" is not suitable and the right one is "you". The use of "Herlina" is wrong because the observer did not ask the students to change the word "tante" into the name of someone. The students were supposed to talk to the second person directly, so they did not have to use Herlina but the second-person pronoun, "you" into the name of someone. But the students were supposed to talk to the second person directly.

To the servant of the students

Kapan bibi pulang ke desa ? (kepada pembantu anda)

when aunt go back to the village?

when servant, go back to a village ?

when Tina go back to the village ?

when will servant go back to your village ?

when will you back to your village?

There were various answers that have been given by the students as the equivalent of the word "bibi" in English, for example, servant, aunt and you, There was also a student who changed the word "bibi" into the name of someone, Tina. Lexically "servant" means bibi. However, if we look back to the context, "servant" should be change into "you". The use of pronoun "aunt" was wrong because "aunt" means younger sister of our mother or father. It does not mean servant or maid. "Tina" was wrong because the observer did not ask the students to use the name of someone instead of "you".

To the teacher of the students

Dimana ibu membeli buku-buku itu ? (kepada guru anda)

Where teacher buy books? 
Where did teacher buy this books?

Where mother buy the book?

When Yayuk buy that book?

When Yayuk buy that book?

There were various answers for the pronoun "ibu" in "Dimana ibu membeli buku-buku itu?" (to the teacher) that students gave such as; teacher, mother, you, and Yayuk. Actually, teacher and mother have the same meaning as ibu. They should change that word into "you" for the correct answer. It is also wrong to use name, "Yayuk", because the observer did not ask the students to change the word "ibu" to the name of the teacher "Yayuk".

Table 3

The Tabulation of the Second Pronoun Used by the Samples

\begin{tabular}{|c|c|c|c|c|c|c|}
\hline \multirow{2}{*}{ ITEM } & \multicolumn{3}{|c|}{ SMP } & \multicolumn{3}{c|}{ SMA } \\
\cline { 2 - 7 } & YOU & KINSHIP & OTHER & YOU & KINSHIP & OTHER \\
\hline $\mathbf{1}$ & 15 & 25 & - & 41 & 119 & - \\
\hline $\mathbf{2}$ & 9 & 31 & - & 30 & 130 & - \\
\hline $\mathbf{3}$ & 10 & 30 & - & 41 & 118 & 1 \\
\hline $\mathbf{4}$ & 2 & 36 & - & 54 & 104 & 2 \\
\hline $\mathbf{5}$ & $?$ & 33 & - & 55 & 93 & 12 \\
\hline $\mathbf{6}$ & 9 & 17 & 14 & 64 & 95 & 1 \\
\hline $\mathbf{7}$ & 19 & 21 & - & 32 & 126 & 2 \\
\hline $\mathbf{8}$ & 1 & 35 & 4 & 48 & 101 & 11 \\
\hline $\mathbf{9}$ & 10 & - & 30 & 28 & 81 & 51 \\
\hline $\mathbf{1 0}$ & 2 & 38 & - & 29 & 130 & 1 \\
\hline Total & 84 & 268 & 48 & 422 & 1097 & 81 \\
\hline
\end{tabular}

Table 4

The Percentages of the Second - Person Pronoun Used by the Samples

\begin{tabular}{|c|c|c|c|c|c|c|}
\hline \multirow{2}{*}{ ITEM } & \multicolumn{3}{|c|}{ SMP } & \multicolumn{3}{c|}{ SMA } \\
\cline { 2 - 7 } & YOU & KINSHIP & OTHER & YOU & KINSHIP & OTHER \\
\hline $\mathbf{1}$ & $37,5 \%$ & $62,5 \%$ & - & $25,6 \%$ & $74,4 \%$ & - \\
\hline $\mathbf{2}$ & $22,5 \%$ & $77,5 \%$ & - & $18,75 \%$ & $81,25 \%$ & - \\
\hline $\mathbf{3}$ & $25 \%$ & $75 \%$ & - & $25,63 \%$ & 73,75 & $0,62 \%$ \\
\hline $\mathbf{4}$ & $5 \%$ & $95 \%$ & - & $33,76 \%$ & $65 \%$ & $1,24 \%$ \\
\hline $\mathbf{5}$ & $17,5 \%$ & $82,5 \%$ & - & $34,37 \%$ & $58,13 \%$ & $7,5 \%$ \\
\hline $\mathbf{6}$ & $22,5 \%$ & $42,5 \%$ & $35 \%$ & $40 \%$ & $59,38 \%$ & $0,62 \%$ \\
\hline $\mathbf{7}$ & $47,5 \%$ & $52,5 \%$ & - & $20 \%$ & $78,76 \%$ & $1,24 \%$ \\
\hline $\mathbf{8}$ & $2,5 \%$ & $87,5 \%$ & $10 \%$ & $39 \%$ & $63,12 \%$ & $6,88 \%$ \\
\hline $\mathbf{9}$ & $25 \%$ & - & $75 \%$ & $17,5 \%$ & $50,63 \%$ & $31,87 \%$ \\
\hline $\mathbf{1 0}$ & $5 \%$ & $95 \%$ & - & $18,13 \%$ & $81,25 \%$ & $0,62 \%$ \\
\hline Total & $210 \%$ & $670 \%$ & $120 \%$ & $263,74 \%$ & $685,67 \%$ & $50,59 \%$ \\
\hline
\end{tabular}

Table 5

Total Percentages of the Pronominals that are used by SMP and SMA Students

\begin{tabular}{|c|c|c|}
\hline \multicolumn{3}{|c|}{ SMP and SMA } \\
\hline YOU & KINSHIP & OTHERS FORM \\
\hline $25,3 \%$ & $69,05 \%$ & $5,65 \%$ \\
\hline
\end{tabular}

The data in the table showed the percentages of the correct and wrong answers of the students in using second-person pronoun. There are $62,5 \%$ of SMP students used "grandfather" and 37,5\% of them used "you" and 74\% of SMA students used "grandfather", 
$25,6 \%$ of them used "you", for pronoun "kakek" in "kakek mau pergi kemana" (where are you going?).

In accordance with the data for pronoun "Ibu" in "Ibu, apa yang sedang ibu cari" (what are you looking for?), there are $77,5 \%$ of SMP students used "mother" and $22,5 \%$ of them used "you", $81,25 \%$ of SMA students used "mother", and 18,75\% of them used "you".

There are $75 \%$ of SMP students used "Aunt" and $25 \%$ of them used "you", and $73,75 \%$ of SMA students used "Aunt", $25,63 \%$ of them used "you", and $0,62 \%$ used other forms, such as "Herlina", for pronoun "Tante" in "Tante mau minum apa" (what would you like to drink?).

There are $95 \%$ of SMP students used "Father"and 5\% of them used "you", $65 \%$ of SMA students used "father", 33,76\% of them used "you", and 1,12\% of students used other forms, such as "Herman" and "Dad", for pronoun "Bapak" in "Bisakah bapak mengantar saya ke sekolah?" (can you accompany me to school?).

In addressing "Bapak" (driver) in "Bisakah bapak menjemput adik sore ini?" (can you pick the brother up this evening?), there are 82,5\% of SMP students used "father", and 17,5\% of them used "you", 58,13\% of SMA students used "father", 34,37\% of them used "you" and 7,5\% of the rest of students used other form, such as "sir".

There are $42,5 \%$ of SMP students used "brother", $22,5 \%$ of them used "you" and $35 \%$ of the rest used others form, such as "He" and 59,36\% of SMA students used "Brother", $40 \%$ of them used "you" and $0,62 \%$ of the rest used "Levina".

For pronoun "Bibi" (servant) in Kapan bibi pulang ke desa? (when will you go to your village?), 52,5\% of SMP students used "servant" and $47,5 \%$ of them used "You" and $78,76 \%$ of SMA students used "servant", $20 \%$ of them used "you" and $1,24 \%$ of the rest used others form, such as; "aunt" and Tina.

$87,5 \%$ of SMP students use "Father", $2,5 \%$ of them used "you", $10 \%$ of the rest used other form, such as "sir", and 63,12\% of SMA students used "father", $20 \%$ of them used "you" and 6,0\% of the rest used other form, such as "sir", for pronoun "Bapak" (the "becak" driver) in Tolong bapak abwakan bunga-bunga in ke rumah pak Amin! (please, bring this flowers to Mr. Amin's house).

For pronoun "Ibu" (teacher) in Dimana Ibu membeli buku-buku itu? (where did you buy shoes books?) $25 \%$ of SMP students used "you", $75 \%$ of them used other forms such as "teacher" and 50,63\% of SMA students used "mother", $17,5 \%$ of them used "you" and $31,25 \%$ of them used others form, such as "teacher" and $0,62 \%$ of the rest used name of someone, "Yayuk".

For the pronoun "Paman in Apakah paman pergi juga malam ini? (will you go, too this night?), $95 \%$ of SMP students used "uncle", $5 \%$ of them used "you" and $81,25 \%$ of SMA students use "uncle", $18,13 \%$ of them used "you" and $0,62 \%$ of the rest used others form, such as "Anthonius".

From the descriptions, it can be seen that $25,3 \%$ students used the correct form "you", $69,05 \%$ students used kinship terms and 5,65\% students used other forms. Therefore, it can be concluded that most students still need guidance in using the second-person pronoun "you" in English.

\section{Discussion}

Based on the above analysis, it indicated that many students use kinship terms instead of the second-person pronoun "you". It may be caused by the influence of Javanese culture in which in Javanese society the younger person are not allowed to use the second - person pronoun "you" to the elders. In fact, they should use kinship terms. Therefore, The habit of using second - person pronoun in their own language is transferred when they used the second-person pronoun in English. 
This case can be related to Derakhshan and Karimi (2015:2112), he claimed that "Almost all of the previous researchers believe that first language has interference in second language acquisition." And they gave some examples, Karim and Nassaji (2013) investigated the first language transfer in L2 writing, and they found that when second language learners write in L2, their L1 has an effect on their writing. Fatemi, Sobhani and Abolhassan (2012) investigated the differences in consonant clusters orally in the first and second language, and pointed out if the structures of first and second language were different, learners have difficulty in L2 pronunciation because they faced to unfamiliar phonological rules, but Lord (2008) did the converse study; he investigated the different effects that L2 acquisition has on L1.

Derakhshan and Karimi (2015:2113), also explained "Learners of second language tend to transfer the forms, meaning and culture of their L1 to the foreign language and culture when attempting to speak the language." "By learning L2 habits, L1 habits are also transferred and then the errors occur", (Beebe \& Seliger, as cited in Nemati \& Taghizadeh, 2006) in Derakhshan and Karimi (2015:2113).

Based on the pronominals that were used by the students, it was found that many students used kinship terms instead of you. It happened since the Javanese should know who are the interlocutors.

Javanese society really pays attention to politeness in their behavior. It also includes when they are talking. They always try to determine the right language before they speak to someone, especially for the elder people. The use of such language also affects the use of address words in Javanese. This is closely related to social values and politeness in Javanese society. Therefore, the choice of pronominals shows the relation between respect, and politeness. The use of such pronominals in the data can also be related to kinships. For instance, the students use the kinships term instead of "You" in the following sentences;

1. Where grandfather will go ? (to your grandfather)

2. What mother looking for? (to your mother)

3. What aunt like to drink? (to your aunt)

4. Can father escort me to school? (to your father)

5. Can pick up brother this evening father? (to your driver)

6. What brother doing every Sunday? (to your brother)

7. When aunt go back to a village? ( to your servant)

8. Please father brings these flowers to Mr. Amin's house. (to "becak" driver)

9. Where mother buy that books? (to your teacher)

10. Will uncle go, too. This night? (to your uncle)

In interaction, Javanese people should consider what is called 'unggah-unggah ing basa, unda-usuk' or 'linguistic etiquette'. 'The Javanese language has a speech level system namely undha-usuk basa or unggah-ungguh basa Jawa",Saddhono et al. (2020). Adisti 2018:207) further stated that "Javanese unggah-ungguh character is one of Indonesian ancestral heritage that must be preserved. It is a national identity that symbolizes the wisdom of local Javanese culture." Many aspects of speech behavior are under control of normsregarding a polite and refined conduct. Therefore, the use of kinship terms instead of "You" to the elders may be influenced by Javanese culture. Although the errors that made by the students maybe, because of the students' competence of English is not perfect yet.

\section{CONCLUSION}

Based on the analysis that $25,3 \%$ of students used the correct form "you" and 69,05\% of students used the "kinship terms" and 5,65\% of students used "other forms", it can be 
concluded that there were some errors made by the Javanese students in using the second person pronoun "you" in English.

\section{REFERENCES}

Adisti, A. (2018). Internalization of Javanese Unggah-Ungguh (Etiquette) Character in Modern Era Through Personality Course at English Education Department. Al-Ishlah: Jurnal Pendidikan, 10(2), 216-230. https://doi.org/10.35445/alishlah.v10i2.89.

Derakhshan, A., \& Karimi, E. (2015). The Interference of First Language and Second Language Acquisition. Theory and Practice in Language Studies, 5(10), 2112-2117. http://dx.doi.org/10.17507/tpls.0510.19.

Fichtner, F., \& Chapman, K. (2011). The Cultural Identities of Foreign Language Teachers. L2 Journal, 3(1), 116-40. https://doi.org/10.5070/12319072.

Fitriah, F., \& Hidayat, D. (2018). Politeness: Cultural Dimensions of Linguistic Choice. IJEE (Indonesian Journal of English Education), 5(1), 26-34. https://doi.org/10.15408/ijee.v4i2.2041.

Formentelli, M. (2009). Address Strategies in a British Academic Setting. Pragmatics, 19(2), 179-196.

Genc, B. \& Bada, E. (2005). Culture in Language Learning and Teaching. The Reading Matrix, 5(1).

Kentary, A., Ngalim, A., \& Prayitno, H. (2015). Tindak tutur ilokusi guru berlatar belakang budaya Jawa: Perspektif gender. Jurnal Pendidikan Humaniora, 16(1), 61-71. https://doi.org/10.23917/humaniora.v16i1.1522.

Krisnanda, N. (2015). ADDRESSING SYSTEM OF KINSHIP TERMS IN JAVANESE SOCIETY: A Case Study among Javanese People Living in Semarang. LANTERN (Journal on English Language, Culture and Literature), 3(4). https://ejournal3.undip.ac.id/index.php/engliterature/article/view/7862.

Kusumastuti F. (2018). Analyzing Address Forms in Chinese and Javanese: A Comparative Study. Proceedings of the Fourth Prasasti International Seminar on Linguistics (Prasasti 2018), 166(4), 388-393. https://dx.doi.org/10.2991/prasasti-18.2018.71.

Mazari, A., \& Derraz, N. (2015). Language and Culture. International Journal of Humanities and Cultural Studies, 2(2), 350-359.

Morin, I. (2005). Translating Pronouns, Proper Names and Kinship Terms from Indonesian into English and Vice Versa. TEFLIN Journal, 16(2), 181-94. https://doi.org/10.15639/teflinjournal.v16i2/181-194.

Nuryantiningsih, F., \& Pandanwangi, W. (2018). Politeness and Impoliteness in Javanese Speech Levels. Proceedings of the Fourth Prasasti International Seminar on Linguistics (Prasasti 2018), 166(4), 388-393. https://dx.doi.org/10.2991/prasasti$\underline{18.2018 .70 .}$.

Quinn, G. (2011). Teaching Javanese Respect Usage to Foreign Learners. Electronic Journal of Foreign Language Teaching, 8, 362-370.

Saddhono, K., Setyawan, B., Raharjo, Y., \& Devilito, R. (2020). The Phenomenon of Using Javanese Speech Levels in Javanese Society: A Sociolinguistic Review. Journal of Talent Development and Excellence, 12(2s), 3989-4002.

Wajdi, M., Darma, L., Suastra, I., \& Budiarsa, I. (2013). Code-Crossing: Hierarchical Politeness in Javanese. E-Journal of Linguistics, 7(1), 1-16. https://ojs.unud.ac.id/index.php/eol/article/view/11196.

Yusuf, Y. Q., Nasir, C., \& Andib, N. (2019). Power and Solidarity: The Pronoun of Address $\mathrm{Ke}[\mathrm{Ke}]$ Used in Indonesian by Acehnese Speakers. International Journal of Language Studies, 13(1), 77-81. 